\title{
Impact of Emerging Engine and After-Treatment Technologies for Improved Fuel Efficiency and Emission Reduction for the Future Rail Diesel Engines
}

\author{
Carlo Beatrice $^{1}$ (D) Natale Rispoli $^{1} \cdot$ Gabriele Di Blasio $^{1}$ • \\ Athanasios G. Konstandopoulos ${ }^{2} \cdot$ Eleni Papaioannou $^{2} \cdot$ Abdurrahman Imren $^{3}$
}

Received: 21 December 2015 /Revised: 18 February 2016 / Accepted: 19 February 2016 / Published online: 9 March 2016

(C) Springer International Publishing Switzerland 2016

\begin{abstract}
The future stringent emission limits and fuel-saving requirements for non-road engines, in particular for the rail sector, require further research investments both on engine and after-treatment technologies. Therefore, the aim of this study is to identify, mainly on a literature data base, the most promising emerging engine technologies (waste heat recovery, turbocharging, etc.) and exhaust after-treatment systems (de- $\mathrm{NO}_{x}$ catalyst systems, particulate filters, etc.) for improved fuel efficiency and emissions reduction of rail diesel engines. The considered technologies are currently from production series or under development mostly in the on-road research domain. The approach taken has been to gather available information and data from research and industry sources for the most promising emerging technologies of on-road heavy-duty (HD) engines. The collected data have been properly analyzed and elaborated in order to identify the most transferable data from road to the rail sector. The study is one of the results of a project carried out within the 7th European Framework program in which several academic and industrial partners have participated. Engine side and exhaust after-treatment system side technologies are discussed separately. The former takes into account quantitative data from the literature survey, mainly in terms of fuel efficiency benefits, and summarizes the evaluation in a return on investment calculation on the base of a reference rail engine cost. In the latter, essentially qualitative information has been collected. The analysis has been
\end{abstract}

Carlo Beatrice

c.beatrice@im.cnr.it

Istituto Motori CNR, Naples, Italy

CERTH/CPERI, Thessaloniki, Greece

3 The Pennsylvania State University, State College, USA carried out by means of spider diagrams that are used to show the potential of the grouped after-treatment technologies in terms of pollutant emission reduction, size/weight reduction, technology maturity, and cost reduction. The results indicate that the emerging engine technologies are mostly about engine efficiency improvements, of which waste heat recovery shows the greatest potential in terms of fuel efficiency improvement. On the after-treatment system side, the integration of multiple after-treatment functionalities into a single device is particularly attractive for rail applications because it could significantly decrease space and weight requirements, as could the use of alternative to urea media for ammonia storage in the case of selective catalytic reduction (SCR) system functionalities.

Keywords Rail diesel engine technologies $\cdot$ After-treatment technologies · Rail diesel engine emissions $\cdot$ Engine technology costs

\section{Introduction}

Tier 4 (US)/Stage IV (EU) is the current step of the emission reduction program launched in 1996 for all non-road equipment. For rail engines with a class power range below $560 \mathrm{~kW}$, the current regulation requires engine manufacturers to reduce the level of nitrogen oxides $\left(\mathrm{NO}_{x}\right)$ emissions to a level that is about $80 \%$ lower than the previous standards Tier 3/Stage IIIB, while particulate matter (PM) emissions have to be reduced by an order of magnitude for US regulation only. The other gaseous pollutant limits remain the same. Table 1 shows the comparison (www.dieselnet.org).

An overview of the implementation timetable of the EU emission limits for all non-road mobile machinery (NRMM) engines is reported in Fig. 1 [1]. 
Table 1 US Tier 3 and 4 regulations versus EU stage IIIB and IV

Emission standards for rail engine with power $\leq 560 \mathrm{~kW}[\mathrm{~g} / \mathrm{kWh}]$

\begin{tabular}{lllllll}
\hline & Year & $\mathrm{CO}$ & $\mathrm{HC}$ & $\mathrm{NMHC}^{2} \mathrm{NO}_{x}$ & $\mathrm{NO}_{x}$ & $\mathrm{PM}$ \\
\hline US & & & & & & \\
$\quad$ Stage Tier 3 & 2006 & 3.5 & - & 4 & - & 0.2 \\
$\quad$ Stage Tier 4 & 2014 & 3.5 & 0.19 & - & 0.4 & 0.02 \\
EU & & & & & & \\
$\quad$ Stage IIIB & 2012 & 3.5 & 0.19 & - & 2 & 0.025 \\
$\quad$ Stage IV & 2014 & 3.5 & 0.19 & - & 0.4 & 0.025 \\
\hline
\end{tabular}

To achieve the new targets, the use of diesel particulate filters (DPFs) and higher levels of exhaust gas recirculation (EGR), and/or SCR systems are required, as indicated in Fig. 2.

However, new stringent regulations are under consideration. As an example, according to European CommissionJoint Research Center (JRC), a study concluded that even the most ambitious levels defined with Stage IV did not guarantee adequate protection from negative health effects of PM emissions [2]. Therefore, in line with the developments in the onroad sector, the introduction of a new emission stage (Stage V) targeting particle number $(\mathrm{PN})$ limits rather than particle mass limits needs to be considered. This should focus on the engines in the power range between 56 and $560 \mathrm{~kW}$, which provide by far the largest contribution to NRMM emissions.
In parallel, the continuous increase of diesel fuel cost in last decades has meant the strong interest for the fuel saving. On the other hand, as the diesel cost rises continuously, it can be only compensated with the adoption of new technologies able to increase the energy efficiency.

To find short and mid-term technological solutions for thermal powertrains of the rail sector is particularly important in order to avoid a partial modal shift from rail sector to the lesssustainable road sector on regional passenger lines and freight transportation specialized routes. In this respect, an European Union co-founded project, entitled "Clean European RailDiesel" (Cleaner-D), has been carried out between the years 2010 and 2013 in order to give a response to the issues reported above and also to find the best balance between environmental and economical requirements (http://www.cleaner-d.eu/).

Referring to the work program of the Cleaner-D project concerning the engine technology, in which authors have been collaborating, one of the target was to have a quantitative evaluation of the current state-of-the-art engine and exhaust after-treatment (EAT) technologies to meet Tier 4/Stage IV standards. In this respect, a quantitative basis analysis of the capacity of the current state-of-the-art engine and EAT technologies (EGR, DPF, and SCR) to meet Stage IIIB and lower emissions limits in diesel railcar applications was performed [3]. In that study, engine simulation tools were applied in order to estimate the emission reduction capabilities and the impact on fuel consumption (FC),

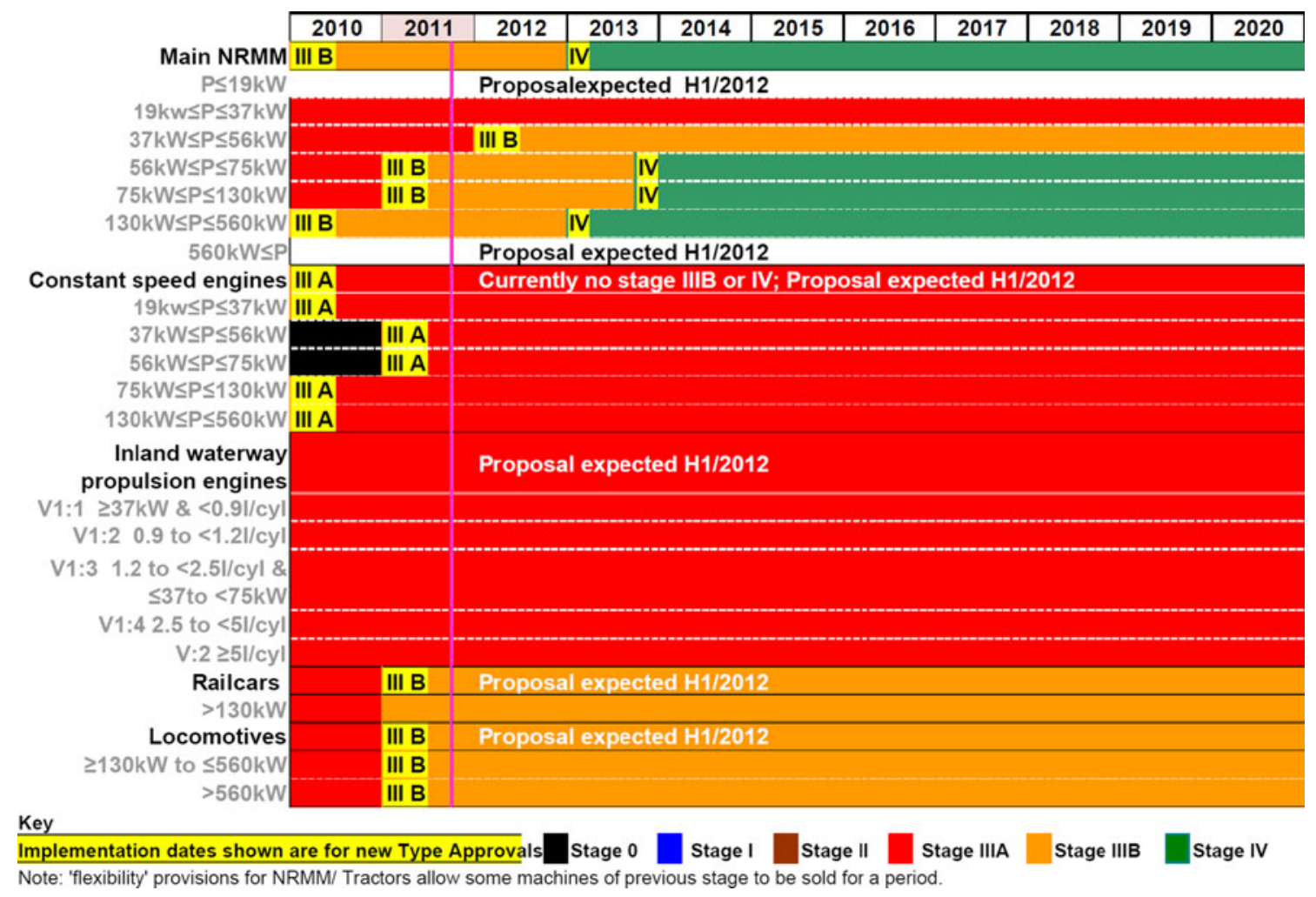

Fig. 1 Railway specific emission regulation 
Fig. 2 EU legislation related to emission standards

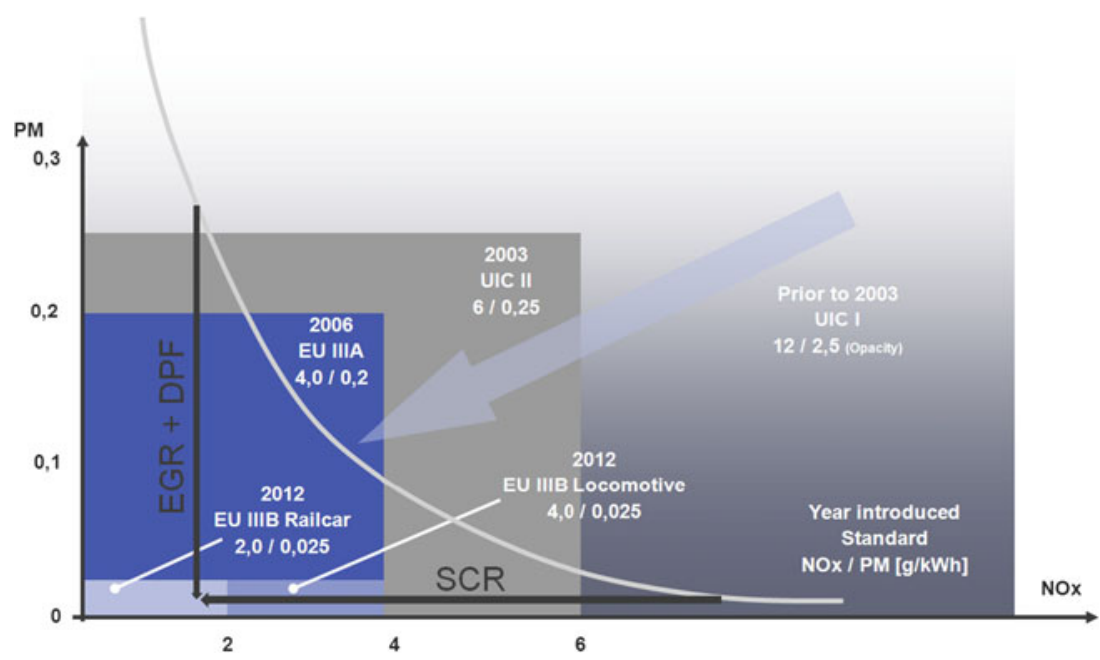

urea consumption (in the case of SCR) and cooling requirements of these technologies on the whole railcar.

Another target of the work program was to identify the most promising solutions under development in the road sector for fuel efficiency improvement and emission reduction beyond the current Tier 4/Stage IV standards and evaluate their impact on rail engines. Such a second goal is important to support the choice of the guidelines for the development of the future rail diesel engines. However, such information is missing in the context of diesel engines for rail applications.

As often happens, a transfer of technologies from the road sector drives the development of NRMM engines. Therefore, the study was based on the gathering of available information from literature survey, research, and industry sources of the most promising technologies currently under development and mostly in the automotive research domain. The methodological approach consisted of: the identification and averaging of data from the most comparable on-road powertrains, with respect to the rail one in terms of engine characteristics and engine and vehicle duty cycle. Then, the gathered data were used for a costbenefit analysis of the selected technologies applied to the rail engines. For clarity, engine side, and exhaust after-treatment system side technologies are discussed separately.

Fuel quality variation or alternative fuels and multi-fuel systems (e.g., dual-fuel configuration) were not considered in the study voluntarily owing to the fact that most of the alternative fuels under study for HD road transport could be potentially employed in the rail sector. However, taking into the complexity of the topic, it has been considered out of scope of the present work requiring a specific study.

In the case of engine side technologies, quantitative estimations in terms of fuel saving and relative costs of the most efficient solutions were collected from the database, permitting the evaluation of the return on investment for a reference railcar engine.

When considering EAT technologies, it was difficult or not yet possible to make any quantitative predictions regarding their impact in areas such as fuel efficiency, emissions reduction performance, space, and weight requirements, cost, etc. Therefore, the collected data have been used to make a qualitative assessment of their likely impact in their performance areas.

Approach used in the study, methodology of the analysis and results are discussed in the following section.

\section{Approach of the Study and Database}

In this study, the approach is to gather information and data from research and industry sources.

The emerging engine technologies concern mostly those under development/research for on-road HD powertrains, and which are potentially transferable to the rail sector.

The analysis carried out was based on a survey of available previous studies as well as technical information from manufacturers. In the last 5 years, six US and two EU studies were carried out in order to identify possible Scenarios. In a chronological order the analyzed public reports are listed in Table 2 [4-11]. The listed reports do not provide a comprehensive review of the technologies for HD engines, but concern technical and cost-benefits analysis of the future technologies for fuel saving and emission reduction of on-road HD engines.

The reports consider a wide range of powertrains, for medium and HD vehicles and for different applications. Therefore, in order to select the transferable data to the rail sector, a cross-checking analysis among the report data and the rail engine features in terms of engine size, power range, application, and duty cycle was done.

This kind of analysis provided the transferable data from road to rail sector of HD engines. It was assessed that the most correlated data are relative to the long haul trucks and the regional diesel multiple unit (DMU) railcars for road and rail sectors respectively. Table 3 displays the average values of the main features for a baseline long haul truck and two representative European DMU railcars. 
Table 2 List and description of the public reports on heavy-duty powertrain efficiency improvement

\begin{tabular}{lll}
\hline Reference & Author & Title \\
\hline$[3]$ & TNO & $\begin{array}{r}\text { Euro VI technologies and costs for heavy-duty } \\
\text { vehicles. The expert panel's summary of } \\
\text { stakeholders responses }\end{array}$ \\
{$[4]$} & FURORE & R\&D technology roadmap \\
{$[5]$} & NESCCAF/ICCT & $\begin{array}{r}\text { Reducing heavy-duty long haul combination } \\
\text { truck fuel consumption and } \mathrm{CO}_{2} \text { emissions }\end{array}$
\end{tabular}

NAS

[7]

NHTSA

AEA/Ricardo

[9]

TIAX

[10]
TRL/Ricardo

GB rail powertrain efficiency improvements
Date Description

2006 Report carried out to support Commission DG environment on the development of EU5 standards for LD vehicles and EU6 standards for HD vehicles. Study based on panel and stakeholder communications. Available online.

2007 Report carried out to consolidate the automotive R\&D technology roadmap for 2020 and beyond among the EU stakeholders. Available online.

2009 Study to provide an assessment of available and emerging technologies for fuel consumption and $\mathrm{CO}_{2}$ emission reduction from heavy-duty long haul trucks in US in the timeframe 2012-2017. Study based on information from the steering committee and model simulation. Available online.

2010 Study commissioned to National Academy of Sciences to assess fuel economy technologies for medium- and heavyduty vehicles (including how such technologies may be practically implemented in vehicles and identifying the potential costs). Information gathered from vehicle manufacturers, component suppliers, research labs, and major fleets during site visits by the committee. Available online.

2010 Study of National Highway Safety Administration of USA to assess factors and measures for fuel economy for Mediumand Heavy-Duty vehicles. Information gathered from vehicle manufacturers, component suppliers, etc. Available online.

2011 Project aimed to produce an initial step in the process of informing possible policy actions for energy saving of EU $\mathrm{HD}$ vehicle market and $\mathrm{CO}_{2}$ emission reduction. Information gathered from OEM, public agencies, literature etc. Available online.

2011 Report based on the comparison of NAS (US) and AEA (EU) studies in order to determine whether conclusions for the US HDV sector may apply to the EU and to quantify the potential GHG reductions that may be achievable. Available online.

2012 Study aimed to identify technology from non-rail sector able to improve energy efficiency of diesel powered rolling stocks. Available online.
From Table 3 it can be noted that the $360 \mathrm{~kW}$ class of rail engines shows very similar features to the $360 \mathrm{~kW}$ truck engines, while the cylinder displacement of the $560 \mathrm{~kW}$ class engine is only slightly higher than that of the truck engine one. The average FC (in grams of fuel per $100 \mathrm{~km}$ ) of truck and $360 \mathrm{~kW}$ rail engine on their respective reference transient cycles also have the same order of magnitude, while the $560 \mathrm{~kW}$ engine has the highest average FC. However, the vehicle transient cycle affects greatly the average FC. As an example, in the case of DMUs, the reference transient cycle includes several starts and stops at the stations, while the truck transient cycle consider less stop and start times. For details, see pages 31 and 32 in [7] and report CLD-D-UIC-013.02 in (http://www.cleaner-d.eu/).
Moreover, certain aspects, to be taken into account for the evaluation of the technologies, need to be clarified:

- Each study is based on a specific data collection methodology and application Scenario. Indeed, as discussed above, evaluation of a different vehicle duty cycle and relative fuel economy is an example. This context changes among the different studies.

- There are several citations of the oldest reports in the new ones, indicating that some information in the most recent reports is based directly on the previous reports.

- It is clearly indicated that there is a tendency among researchers to evaluate technologies under conditions which are best suited to that specific technology. This can be an 
Table 3 Specification comparison for engines employed for $370 \mathrm{~kW}$ HD on-road truck, $360 \mathrm{~kW}$ railcar, and $560 \mathrm{~kW}$ railcar, respectively

\begin{tabular}{|c|c|c|c|}
\hline \multirow[b]{2}{*}{ Features } & \multicolumn{3}{|l|}{ Vehicle } \\
\hline & Long-haul truck & $\begin{array}{l}\text { Regional 3-coach } \\
\text { DMU railcar }\end{array}$ & $\begin{array}{l}\text { Regional 3-coach } \\
\text { DMU railcar* }\end{array}$ \\
\hline Displacement (1) & $\approx 13$ & $\approx 13$ & $\approx 20$ \\
\hline Cylinder displacement (1) & $\approx 2.1$ & $\approx 2.1$ & $\approx 2.5$ \\
\hline Popular architecture & 6 in-line cylinders & 6 in-line cylinders & $8 \mathrm{~V}$ cylinders \\
\hline Rated power (kW @ rpm) & $370 @ 2100$ & $360 @ 1800$ & $560 @ 2100$ \\
\hline Vehicle gross weight range $(\mathrm{kg})$ & $16000-40000$ & $30000-40000$ & $50000-60000$ \\
\hline Minimum specific fuel consumption (g/kWh) & $180-190 * *$ & $195-200 * * *$ & $195-200 * * *$ \\
\hline $\begin{array}{l}\text { Average fuel consumption on transient cycle } \\
(1 / 100 \mathrm{~km})^{\mathrm{a}}\end{array}$ & $\approx 72 * *$ & $\approx 108 * * * *$ & $\approx 126 * * *$ \\
\hline Emission control system & $\mathrm{EGR}+\mathrm{DPF}+\mathrm{SCR}$ & $\mathrm{EGR}+\mathrm{DPF}$ & $\mathrm{EGR}+\mathrm{DPF}$ \\
\hline Emission limits & EU VI & IIIB & IIIB \\
\hline
\end{tabular}

$D M U$ diesel multiple unit, $E G R$, exhaust gas recirculation, $D P F$, diesel particulate filter, SCR, selective catalytic reduction

${ }^{\mathrm{a}}$ Transient cycle is referred to the duty cycle of the respective vehicle

*Each coach has one engine and values are referred to a single coach

$* *[7]$

$* * *$ (http://www.cleaner-d.eu/)

issue in situations where performance becomes strongly dependent on duty cycle.

- In some reports, the fuel type and fuel technology was also evaluated. In the present study, this aspect is not considered.

Apart the aspects above that have to be taken into account when the information reported, even if differences in some features exist, the comparison in Table 3 legitimates the transfer of cost-benefits data from the on-road HD engines to rail sector, in particular for DMU applications. In principle, the data could be also considered valid for engines with power output up to $560 \mathrm{~kW}$ for railcar applications but cannot be extended to larger engines for heavy haul locomotives.

\section{Analysis of the Engine Emerging Technologies}

From the engine side, several technologies are almost ready for production or in an advanced development step. A brief list of the key points of each technology that can contribute to FC and emission reduction is given below. It is important to point out that the description in the following does not represent a technical review of the technologies, but a mere list of the main features of the technologies taken into account in the cost-benefit analysis. Therefore, the references listed below in addition to the reports have been considered as bibliography examples of how each feature affects the $\mathrm{FC}$ and the pollutant emissions.

\section{(a) Fuel injection systems (FIS)}

The following features of the FIS have been considered for fuel efficiency improvement of rail engines $[6,7,10,12-16]$ :

- Very high-pressure fuel injection;

- Advanced nozzle design;

- Finely shaped and controlled spray;

- Multiple injection;

- Improved control with more accurate timing and metering of injection.

(b) Advanced EGR systems

Regarding the EGR loop the following options has been considered $[6,7,9,10,12,17-20]$ :

- Low temperature EGR and as a result advanced injection timing (Because of lower exhaust temperature this technology is not compatible with exhaust energy recovery systems.)

(c) Advanced turbochargers

Turbocharging represents one of the most important component affecting engine efficiency and emissions. The main features under study are $[6,7,9,10,12,21-23]$ :

- Higher pressure ratio compressors;

- Producing adequate EGR flow without reducing turbo efficiency;

- Two turbochargers in series with intercooling for higher turbocharger efficiency;

- Modulated two-stage systems;

- Mechanical or electrical turbo-compound. 
(d) Combustion system design and advanced combustion control

Combustion system design features like piston geometry, compression ratio, intake, and exhaust port design, greatly affect combustion process evolution, pollutant formation, and fuel efficiency. Moreover, higher power density is desired in order to apply the engine downsizing concept for fuel saving, while innovative premixed/homogeneous based combustion processes are under study for the sake of improving the pollutant emissions without sacrificing the high efficiency of the diesel cycle. The main features under investigation are [6-8, 12, 14, 18, 24-28]:

- Improved combustion chamber to improve air management and mixing;

- Improved materials and structural design for higher cylinder pressures;

- Alternatives to the standard diesel combustion such as low-temperature combustion (LTC), homogeneous charge compression ignition (HCCI), and premixed charge compression ignition (PCCI) to lower engine-out emissions in certain operating conditions;

- Engine efficiency improvements due to closed-loop control;

- Adding $200 \mathrm{lb} / \mathrm{ft}$ of torque in the top two transmission gears so that there is no need to reduce the downshifting on modest grades;

- Electronic controller with model-based controls;

- More sophisticated control (e.g., upgraded fuel system capabilities, sophisticated control algorithms, additional sensor inputs for feedback control).

\section{(e) Variable valve actuation (VVA)}

VVA is one of the most effective solution to control in-cylinder thermodynamic conditions and in consequence fuel ignition, combustion process evolution, and depending on the system flexibility, to permit advanced engine cycle emulation (e.g., miller cycle). Therefore, two features of the VVA system are considered effective for engine efficiency improvement $[6,7,29]$ :

- Valve actuation (timing, duration, and lift) independently from the crankshaft angle;

- Cylinder deactivation.

\section{f. Waste heat recovery $(W H R)$}

From the point of view of the fuel saving technology roadmap, WHR represents the most attractive sector. Two key technologies are mainly under development [6-8, 21, 24, 30-33]:

- Secondary engine that uses exhaust energy or other heat sources from the primary engine to develop additional power without using additional fuel;

- Sources of energy to power a bottoming cycle can include the EGR stream, exhaust stream, charge air stream, and engine coolant circuit.

\section{(g) Electrification of engine-driven accessories}

The substitution of mechanical driveline of several accessories like water-pump etc. has also a good potential for fuel saving. More features under study are, [7, 9, 10]:

- Accessories can be electrically powered, which has the advantage to operate only when needed;

- Accessories can run at speeds independent of engine speed, which can reduce power consumption;

- Electrification of accessories will have more effect in short-haul/urban applications and less benefit in linehaul applications.

On the base of the fuel consumption improvement estimation versus technology, listed above, and on the capital cost of each one (development costs are not considered) reported in [8], the average fuel efficiency benefits versus engine cost increment has been assembled for road HD $370 \mathrm{~kW}$ class engines for long haul truck applications.

In order to transfer the cost-benefit data on the rail sector, a survey was carried out within the Cleaner-D consortium to define the capital cost of a reference rail engine and additional parameters for the return on investment calculation. An engine base cost of $€ 70,000$ for a $560 \mathrm{~kW}$ class engine has been considered (http://www. cleaner-d.eu/). Table 4 shows the results. A further criteria which is shown in Table 4 is the own weight with respect to the engine weight.

It is important to note that there may be some redundancy in the percentages quoted. It should also be considered that some technologies influence each other in a negative way. So the fuel improvements cannot be summed linearly. For further details, see $[6,7]$.

The return on the investment calculation has been carried out by taking into account the engine cost increments, the fuel efficiency improvements, the fuel cost and its consumption for a reference working day. The corresponding values are listed in the following (http://www.cleaner-d.eu/):

- Operating hours: $14 \mathrm{~h}$ per day

- Diesel costs: $€ 1.30 /$ liter

- Fuel density: $850 \mathrm{~g} / \mathrm{dm}^{3}$

- Average fuel consumption: $25000 \mathrm{~g} / \mathrm{h}$ 
Table 4 List of engine emerging technologies versus costs, fuel consumptions, and weights

\begin{tabular}{|c|c|c|c|}
\hline Technology & $\begin{array}{l}\text { Engine cost increment }(\%) \\
\text { (engine baseline cost }=€ 70,000)\end{array}$ & $\begin{array}{l}\text { Fuel efficiency improvement } \\
\text { (\%) (Euro V as baseline value) }\end{array}$ & $\begin{array}{l}\text { Additional weight related } \\
\text { to engine weight }[\%]\end{array}$ \\
\hline Fuel injection systems & From 0 to $1 \%$ & From 1.5 to $3.2 \%$ & From 0 to $1 \%$ \\
\hline Advanced EGR & From 0.5 to $1 \%$ & From 1 to $1.5 \%$ & From 0 to $2 \%$ \\
\hline Advanced turbochargers & From 0.3 to $1 \%$ & From 1 to $2 \%$ & From 0 to $2 \%$ \\
\hline Combustion system design & From 0.5 to $1.5 \%$ & From 1 to $3 \%$ & From 0 to $1 \%$ \\
\hline Advanced combustion & $\sim 10 \%$ & From 1 to $2 \%$ & 0 \\
\hline Advanced combustion control & From 0.1 to $0.15 \%$ & From 1 to $3 \%$ & 0 \\
\hline Variable valve actuation & $\sim 0.3 \%$ & $\sim 1 \%$ & From 0.5 to $3 \%$ \\
\hline Waste heat recovery & From 5 to $20 \%$ & From 4 to $8 \%$ & From 6 to $20 \%$ \\
\hline $\begin{array}{l}\text { Electrification of engine-driven accessories and } \\
\text { auxiliaries }\end{array}$ & From 0 to $2 \%$ & From 0 to $3 \%$ & From -1 to $2 \%$ \\
\hline
\end{tabular}

The results of the calculations are summarized in Fig. 3.

The pessimistic estimation has been calculated in a way that the lowest fuel improvement and the highest cost increment are assumed. The optimistic way considers the highest fuel improvement estimation and the lowest cost increment.

Figure 3 shows that the return on investment is less than 1 year in most cases. Only "advanced combustion" and the pessimistic consideration of WHR run away. This is why both advanced combustion and WHR technologies are characterized by the highest costs of investment (Table 4). However, the WHR technologies show the highest potential in terms of FC reduction, and by taking into account the huge current efforts in research and development in this field, the topic appears as the most strategic of the long-term solution for fuel efficiency improvement. On the other side, the listed features of the "advanced combustion" technologies appear as strategic not only for FC improvements but also in terms of pollutant emission control, noise vibration and harshness (NVH) performance.

This section shows the capability of engine emerging technologies for fuel efficiency improvement for rail heavy-duty engine in a class power up to $560 \mathrm{~kW}$. Except WHR, the influence on the design of the vehicle is only small, because it affects only the engine.

Matching lower emission levels generally influences the fuel consumption in a negative way (e.g., DPF or NOx removal technologies). Therefore, it is important to have technologies as described above which work against this trend.

\section{Analysis of the Exhaust After-Treatment System Emerging Technologies}

As already stated, exhaust after-treatment will be the key technology area for meeting future pollutant emissions regulations. The listed technologies below are based on the following sources:

- The strategic research agendas (SRA) of the European Road Transport Research Advisory Council (ERTRAC), September 2011 [34].

- Published material in the DieselNet (www.dieselnet.org) technology guide.

- Several scientific papers [35-50].

- Information exchanged during the participation of the authors from CERTH in several meetings of the advanced internal combustion engine (AICE) task force of the European Automotive Research Partner Association (EARPA) (www.earpa.org).

The emerging technologies that are in the research phase of development are presented in the following:

(a) DPF related:

- DPF with membrane coating;

- DPF with heat recovery;

- New DPF substrate materials;

- Catalyst synthesis and application;

- Electrified DPF;

(b) SCR related:

- Solid ammonia storage;

- Zonal coating of SCR;

- $\mathrm{LNT}+\mathrm{SCR}$;

(c) System level technology themes:

- On-board monitoring and diagnostics;

- Fuel-tailored emission control system;

- Precious metal substitution. 
Fig. 3 Return on investment study of engine emerging technologies

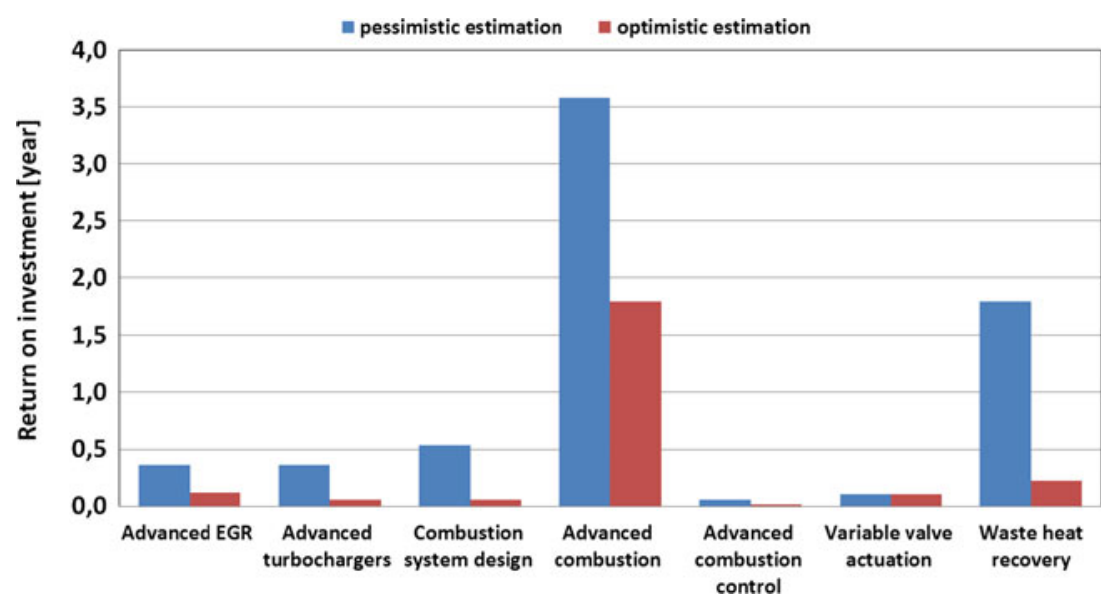

The impact potential and maturity of these technologies can be assessed with respect to:

- Pollutant emissions reduction potential;

- Cost reduction potential (manufacturing cost + system operating cost);

- After-treatment system size and/or weight reduction potential;

- Technology maturity;

On a qualitative basis, the impact potential of the emerging technologies can therefore be visualized using the following spider diagrams (Figs. 4, 5, and 6) for the three technology areas. For the interpretation of these diagrams it is noted that the ranking is relative along each axis and applies only to the technologies depicted on the diagram; the ranking of different technologies on different diagrams should not be compared. The ranking of the technologies is the result of a review analysis within the partner consortium Cleaner-D based on the cited literature and internal communication within the consortium (http://www.cleaner-d.eu/).

Emerging exhaust after-treatment technologies focus mainly on increasing emissions reduction performance, reducing space requirements, reducing the fuel consumption penalty associated with their use, improving system monitoring and control, and reducing their production cost. It is worth noting that the first point among the others is the most important for railcar manufacturers.

In the area of particle emissions control, emerging technologies concentrate mainly on improved regeneration performance and monitoring of the DPF due to its importance for fuel economy. In the area of NOx control, emerging alternative ammonia storage media and LNT + SCR strategies could significantly reduce space requirements. Others technologies with potentially high impact on rail applications are emerging catalyst synthesis that could enable the integration of multiple aftertreatment functionalities into a single device (e.g., DPF
Fig. 4 Impact potential and maturity of DPF related emerging technologies

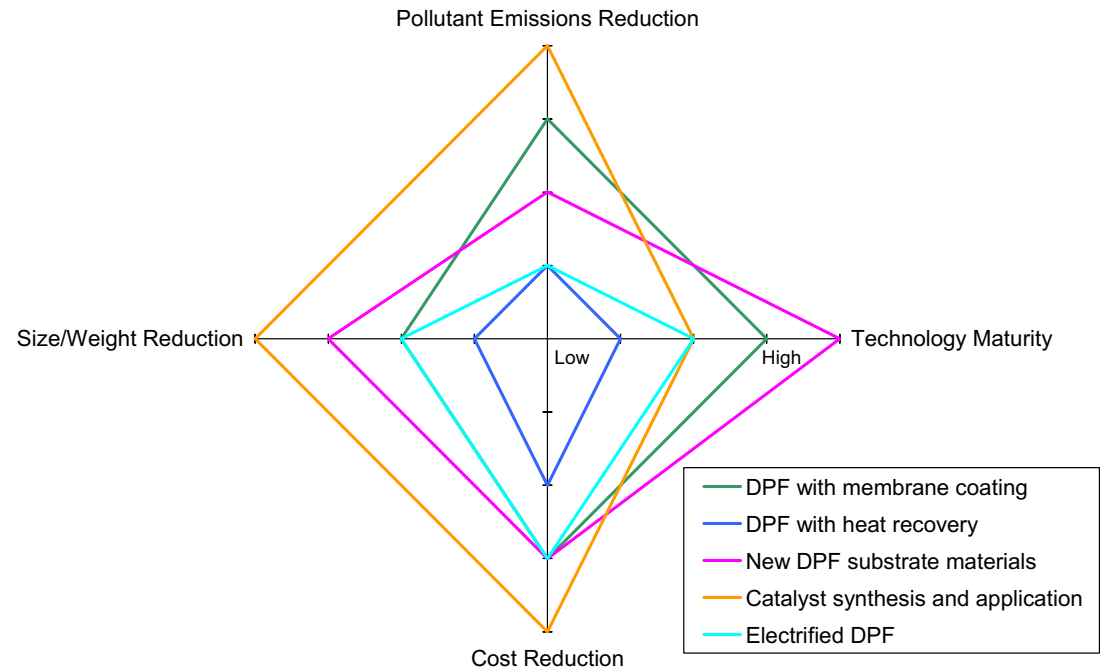


Fig. 5 Impact potential and maturity of SCR related emerging technologies

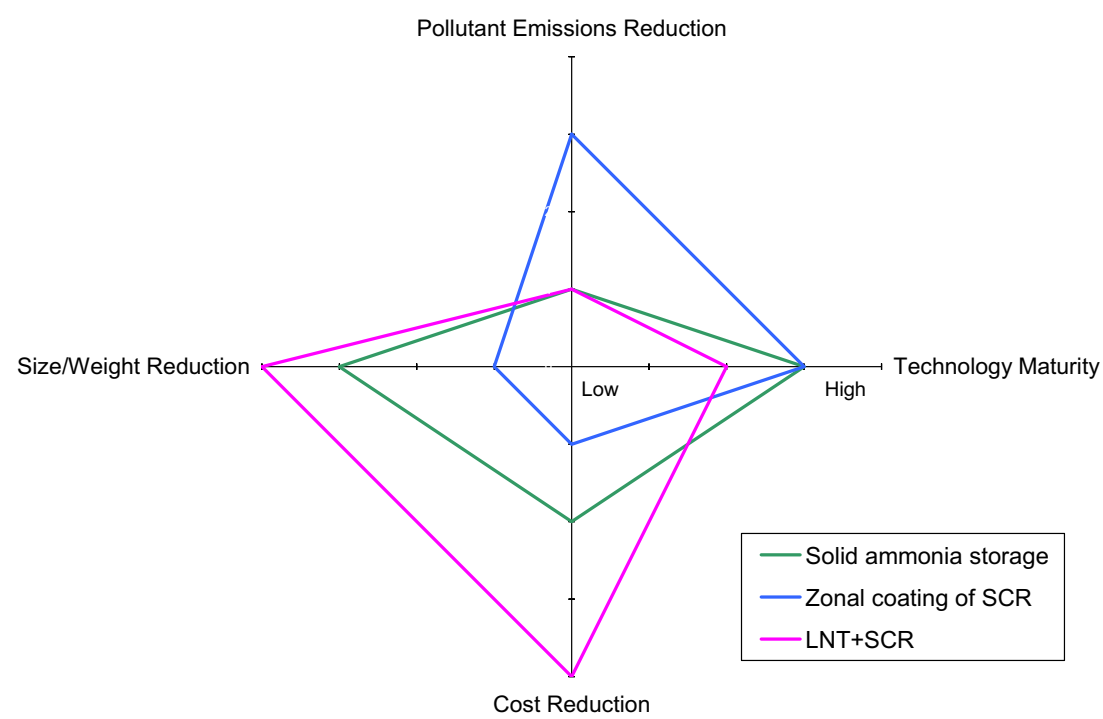

While fuel consumption technologies refer to in-engine modifications that have almost no influence on the vehicle in terms of design and structure (apart that relative to the WHR), the after-treatment technologies will define the appearance of the railcars of the future. Therefore, the task is to develop highly efficient, compact and light after-treatment technologies.

However, there are many additional topics as regeneration, maintenance, long-term durability, safety, engine interaction (back pressure), complexity of the control, and reliability which have to be considered as well.

\section{Conclusions}

The evaluation of the emerging technologies for rail engine sector with class power up to $560 \mathrm{~kW}$ shows that there are
Fig. 6 Impact potential and maturity of emerging aftertreatment system level technology themes

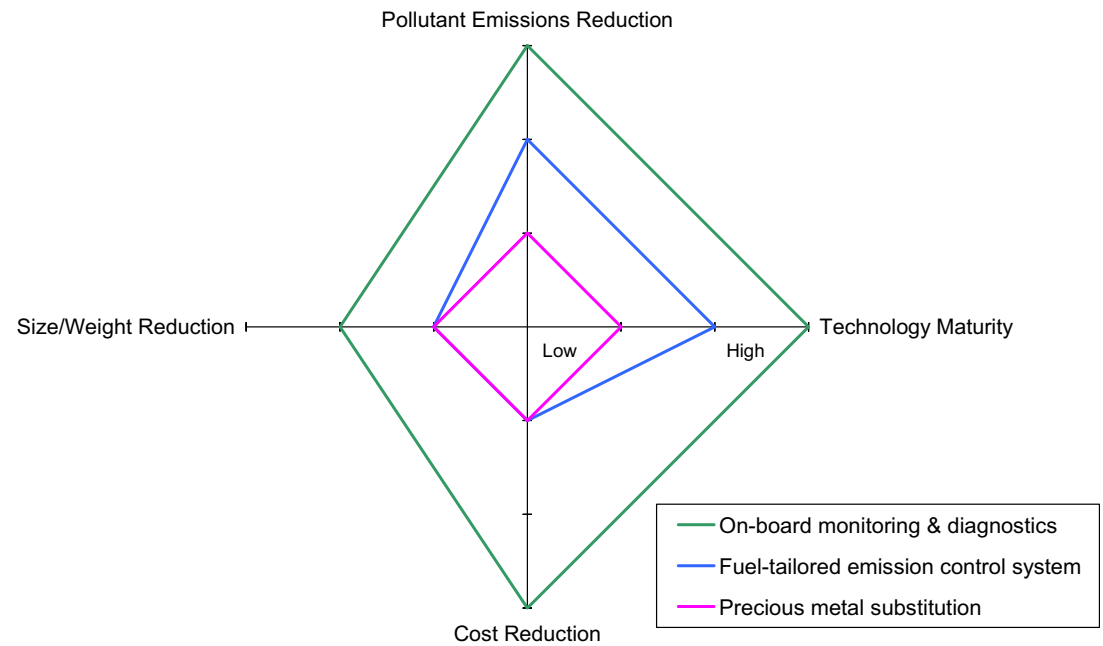


Table 5 Engine emerging technologies

\begin{tabular}{|c|c|c|c|}
\hline Technology & Development status & Advantages & Possible issues \\
\hline FIS $[6,12-15]$ & $\begin{array}{l}\text { - CR systems (both solenoid and piezo) are } \\
\text { the mainstream FIE technology and are } \\
\text { continuously being improved to achieve } \\
\text { higher injection pressures (IP); Max IP of } \\
2500 \text { bar is the current status for the best } \\
\text { systems (developing both pump and } \\
\text { injector); A target of } \approx 3000 \text { bar under } \\
\text { development }\end{array}$ & $\begin{array}{l}\text { - Reduced soot formation } \\
\text { - Adjusting the EGR level, at same exhaust } \\
\mathrm{NO}_{x} / \mathrm{PM} \text { trade-off, less BSFC is } \\
\text { obtainable } \\
\text { - Improved fuel rate control }\end{array}$ & $\begin{array}{l}\text { - Long-term durability of the fuel rate } \\
\text { control } \\
\text { - Cost } \\
\text { - Increased cooling circuit volume due } \\
\text { to high EGR level }\end{array}$ \\
\hline $\begin{array}{l}\text { EGR }[6,8,11 \\
\quad 16-19,23]\end{array}$ & $\begin{array}{l}\text { - HPEGR is a mature technology; current } \\
\text { developing area is for super-cooling } \\
\text { capability, gas flow rate increment and } \\
\text { pressure loss reduction. } \\
\text { - LPEGR is under developing for a large } \\
\text { scale use. }\end{array}$ & $\begin{array}{l}\text { - HPEGR: robust and low cost system for } \\
\mathrm{NO}_{x} \text { emission reduction. } \\
\text { - LPEGR: higher cold EGR flow w.r.t } \\
\text { HPEGR; at same PM/NO } \text { N }_{x} \text { trade-off } \\
\text { lower penalty on BSFC w.r.t. HPEGR }\end{array}$ & $\begin{array}{l}\text { - HPEGR: additional cost for larger } \\
\text { components and improved control } \\
\text { tools; packaging. } \\
\text { - LPEGR: fouling and corrosive } \\
\text { phenomenon on intake pipe } \\
\text { component (compressor, CAC etc.); } \\
\text { high cost; packaging; additional } \\
\text { costs for control development } \\
\text { (special in transient maneuvers) } \\
\text { - SCR required to achieve very low } \\
\mathrm{NO}_{x} \text { emission. }\end{array}$ \\
\hline $\begin{array}{l}\text { Advanced } \\
\text { Turbocharging } \\
{[5,6,8,20-22]}\end{array}$ & $\begin{array}{l}\text {-2-stage turbochargers in production; 3- } \\
\text { stage TC in development. } \\
\text { - Turbo-compounding and E-turbo under } \\
\text { development/research phase; their } \\
\text { application in combination with } \\
\text { bottoming cycle solutions. }\end{array}$ & $\begin{array}{l}\text {-2-stage turbochargers: higher boost } \\
\text { pressure; reduced TC size; robust } \\
\text { technology. } \\
\text { - Turbo-compound and E-turbo: very good } \\
\text { engine response and drivability; exhaust } \\
\text { energy transferred from turbine to } \\
\text { crankshaft; key to superior fuel } \\
\text { economy; for E-turbo independent } \\
\text { control of engine speed and turbine } \\
\text { speed makes E-turbo slightly more } \\
\text { efficient than Turbo-compound, }\end{array}$ & $\begin{array}{l}\text {-2-stage turbo: complex control, if } \\
\text { intercooling is used between the two } \\
\text { turbo and before the intake } \\
\text { manifold; an EGR pump could be } \\
\text { required to facilitate EGR flow } \\
\text { management; possible acid water } \\
\text { condensation in the downstream } \\
\text { compressor; packaging of 2-stage } \\
\text { TC is sometime complex and } \\
\text { difficult with the intercooling. } \\
\text { - Long-term durability of turbo- } \\
\text { compound should to be verified; E- } \\
\text { turbo is ideal application is for } \\
\text { hybrid systems. }\end{array}$ \\
\hline $\begin{array}{l}\text { Combustion system } \\
\text { design }[5-7,11 \\
13,17,24,25]\end{array}$ & $\begin{array}{l}\text { - Conventional diesel: refinement is under } \\
\text { development continuously. }\end{array}$ & $\begin{array}{l}\text { - Conventional diesel: very robust } \\
\text { application and very effective for } \\
\text { combustion control; high torque/power } \\
\text { density, durability, overall pollutant } \\
\text { emissions control. }\end{array}$ & $\begin{array}{l}\text { - Conventional diesel: after-treatment } \\
\text { systems required for pollutant } \\
\text { emission control; further } \\
\text { improvement of the combustion } \\
\text { process subordinated to the injection } \\
\text { system, EGR, air charging etc. }\end{array}$ \\
\hline $\begin{array}{l}\text { Advanced } \\
\text { combustion [5, } 6 \text {, } \\
\text { 11, 13, 17, 24, } \\
26,27] .\end{array}$ & $\begin{array}{l}\text { - Advanced combustion design (for low } \\
\mathrm{NO}_{x} / \mathrm{PM} \text { combustion as HCCI/PCCI/ } \\
\text { LTC): Partially applied in a limited } \\
\text { engine operating range; they are still in } \\
\text { research phase for a larger application }\end{array}$ & $\begin{array}{l}\text { - Advanced combustion: very effective for } \\
\text { engine out } \mathrm{NO}_{x} \text { and } \mathrm{PM} \text { reduction; } \\
\text { potential for overall emission reduction } \\
\text { in future at almost same BSFC in the } \\
\text { low/partial load of the engine operating } \\
\text { area }\end{array}$ & $\begin{array}{l}\text { - Advanced combustion: same } \\
\text { combustion efficiency of } \\
\text { conventional Diesel one, but only in } \\
\text { a limited operating range (20-40\% } \\
\text { of load); little impact on the fuel } \\
\text { economy for engine that operates } \\
\text { most of the time at higher loads } \\
\text { (long-haul truck application); } \\
\text { complex combustion control; high } \\
\text { unburned gaseous emissions; after- } \\
\text { treatment system required. }\end{array}$ \\
\hline $\begin{array}{l}\text { Combustion control } \\
{[6,7,25-27]}\end{array}$ & $\begin{array}{l}\text { - In production for some top class passenger } \\
\text { car engines; under development for large } \\
\text { scale application. } \\
\text { - Under development for HD application. }\end{array}$ & $\begin{array}{l}\text { - Overall improvement of combustion } \\
\text { control in real time; pollutant emission } \\
\text { and fuel consumption reduction; fuel } \\
\text { quality influence mitigation; easier } \\
\text { application of advanced combustion } \\
\text { system. } \\
\text { - High potential for precise combustion } \\
\text { evolution control; fuel quality detection; } \\
\text { better after-treatment management }\end{array}$ & $\begin{array}{l}\text { - Long-term durability; cost; complex } \\
\text { control methodologies. }\end{array}$ \\
\hline $\operatorname{VVA}[5-7,13,28]$ & - In production on SI passenger car engines. & $\begin{array}{l}\text { - Huge impact on engine performance and } \\
\text { fuel economy for SI engines, for HD }\end{array}$ & $\begin{array}{l}\text { - Long-term durability; high cost; } \\
\text { complex engine architecture; }\end{array}$ \\
\hline
\end{tabular}


Table 5 (continued)

\begin{tabular}{|c|c|c|c|}
\hline Technology & Development status & Advantages & Possible issues \\
\hline & $\begin{array}{l}\text { - Under development for LD and HD } \\
\text { Diesel engines }\end{array}$ & $\begin{array}{l}\text { Diesel engines the potential benefits are } \\
\text { limited; flexibility to operate a TC at a } \\
\text { more efficient point on the compressor } \\
\text { map (SCR temperature management } \\
\text { could be an issue); improvement of the } \\
\text { power output of a turbo-compound; high } \\
\text { flexibility of the engine control during } \\
\text { transient phases; quite mandatory for } \\
\text { large application of advanced } \\
\text { combustion system. }\end{array}$ & $\begin{array}{l}\text { packaging; sophisticated control } \\
\text { methodologies. }\end{array}$ \\
\hline $\begin{array}{l}\text { WHR [5, 6, 8-11, } \\
\begin{array}{l}\text { 13, 17, 20, 23, } \\
\text { 24, 29-32]. }\end{array}\end{array}$ & $\begin{array}{l}\text { - In development/research domain } \\
\text { - Turbo-compound and E-turbo also } \\
\text { considered bottoming cycle solutions }\end{array}$ & $\begin{array}{l}\text { - Recovery of "free" energy; fuel } \\
\text { consumption reduction. }\end{array}$ & $\begin{array}{l}\text { - High cost; efficiency is limited by the } \\
\text { amount (flow rate) and quality } \\
\text { (temperature) of waste heat sources; } \\
\text { disadvantaged by variability in heat } \\
\text { sources linked to varied driving } \\
\text { conditions; amount of energy } \\
\text { available is strongly dependent on } \\
\text { engine speed and load; packaging; } \\
\text { others issues related to the freezing } \\
\text { and surviving on-road vibration. }\end{array}$ \\
\hline $\begin{array}{l}\text { Electrification } \\
\quad[6,8,9]\end{array}$ & $\begin{array}{l}\text { - Available for some modern vehicles } \\
\text { - Other solutions in development }\end{array}$ & $\begin{array}{l}\text { - Reduction of the amount of energy } \\
\text { required to drive the accessories. } \\
\text { - Lower fuel consumption and lower GHG } \\
\text { emissions. }\end{array}$ & - Costs, durability, safety \\
\hline
\end{tabular}

technologies to meet lower emission levels in the future. The identified emerging engine and exhaust after-treatment system technologies have the potential to improve fuel efficiency and emissions reduction.

The discussed technologies are mature or under development in the on-road sector. Where possible, the quantitative evaluation of the potential of technologies has been carried out. In particular this is the case of technologies concern the fuel efficiency improvement. In the case of after-treatment technologies, most of them are under development; then, the relative analysis has a qualitative base. It is important point out that most of the emerging technologies are only tested in automotive applications. However, it is considered that the transfer of these technologies into railway applications has to be applicable in the future when considering upcoming more stringent emission legislations for all non-road equipment.

The evolution of heavy-duty powertrains toward future emission regulations will include both after-treatment system development as well as engine measure solutions. The common opinion of the stakeholders is that future emission targets (2020 and beyond) will be met by the integration of several technologies. The combination of the different technologies will depend on many factors, such as the application scenario, a working duty cycle, costs, reliability, packaging, etc.

The after-treatment systems (DPF, SCR, etc.) will play the main role in pollutant emissions control, and the applied solutions for each type of powertrain will be drawn from the best combinations of the previous mentioned factors. In this respect, pollutant emissions control by means of engine measures will play a secondary role, while engine $R \& D$ activities will focus on fuel consumption reduction. Therefore, the key factor for simultaneous pollutant emissions and fuel consumption reduction is - and will be - the correct integration of those emerging technologies that will be gradually available for production series application.

The study showed that cutting the emission levels has the tendency to yield to heavier and bigger propulsion units. In addition the fuel consumption rises which likely can be compensated with engine emerging technologies. Nevertheless, it is not so straightforward to achieve, because most of these technologies tend to lower the exhaust temperature, which has a negative influence on the after-treatment system's efficiency.

AICE, advanced internal combustion engine; DPF, diesel particulate filter; $\mathrm{CO} 2$, carbon dioxide; $\mathrm{CR}$, common rail; CRT, continuously regenerating trap (trademark of Johnson Matthey); DI, direct injection; DMU, diesel multiple unit; DOC, diesel oxidation catalyst; DPF, diesel particulate filter; EEA, European environmental agency; EGR, exhaust gas recirculation; EARPA, European Automotive Research Partner Association; EAT, exhaust after treatment; ERTRAC, European Road Transport Research Advisory Council; FC, fuel consumption; FIS, fuel injection systems; HCCI, homogeneous charge 
Table 6 Exhaust after-treatment system emerging technologies

\begin{tabular}{|c|c|c|c|}
\hline Technology & Development status & Advantages & Possible issues \\
\hline $\begin{array}{l}\text { DPF with porous membrane } \\
\text { coating on the inlet channels } \\
\text { [38]. }\end{array}$ & $\begin{array}{l}\text { - Tests on plate and honeycomb filters have } \\
\text { demonstrated higher clean filter filtration } \\
\text { efficiency and lower pressure drop due to } \\
\text { reduced deep bed filtration. }\end{array}$ & $\begin{array}{l}\text { - Reduced back pressure can enable smaller DPF } \\
\text { volumes and/or lower fuel economy penalty. } \\
\text { - Linear variation of pressure drop with soot mass } \\
\text { load can improve monitoring and regeneration } \\
\text { control } \\
\text { - More rational soot-catalyst contact due to } \\
\text { membrane could enable lower catalyst loadings }\end{array}$ & $\begin{array}{l}\text { - Long-term durability of } \\
\text { membrane coating } \\
\text { - Additional cost of coating } \\
\text { the DPF }\end{array}$ \\
\hline $\begin{array}{l}\text { DPF with internal heat recovery } \\
\text { for improved regeneration } \\
{[45,46]}\end{array}$ & $\begin{array}{l}\text { - Experimental tests have shown faster } \\
\text { thermal response and homogeneous in- } \\
\text { filter temperatures during active } \\
\text { regeneration, leading to lower } \\
\text { regeneration fuel economy penalty }\end{array}$ & $\begin{array}{l}\text { - Improved filter durability due to lower thermal } \\
\text { stressing of substrate under active regeneration }\end{array}$ & $\begin{array}{l}\text { - Additional cost due to } \\
\text { more complicated } \\
\text { manufacturing process }\end{array}$ \\
\hline $\begin{array}{l}\text { New DPF substrate materials } \\
\text { [36] }\end{array}$ & $\begin{array}{l}\text { - Development of new aluminum titanate } \\
\text { compositions with lower porosity but } \\
\text { improved pore design }\end{array}$ & $\begin{array}{l}\text { - Can enable higher soot mass loads or lower } \\
\text { substrate pressure drop without compromising } \\
\text { thermal toughness }\end{array}$ & \\
\hline \multicolumn{4}{|l|}{$\begin{array}{l}\text { Catalyst synthesis and } \\
\text { application: }\end{array}$} \\
\hline $\begin{array}{l}\text { - Gas oxidation } / \mathrm{NO}_{x} \text { reduction } \\
\text { and soot oxidation catalyst on } \\
\text { a single DPF substrate [48] }\end{array}$ & $\begin{array}{l}\text { - Prototypes developed and assessed with } \\
\text { on-vehicle tests }\end{array}$ & $\begin{array}{l}\cdot \text { Low pressure drop } \\
\text { - High gas oxidation activity } \\
\text { - High catalytic soot activity }\end{array}$ & $\begin{array}{l}\text { - Low } \mathrm{NO}_{x} \text { reduction } \\
\text { - Durability needs to be } \\
\text { verified }\end{array}$ \\
\hline $\begin{array}{l}\text { - Integration of SCR catalysts in } \\
\text { DPF }[37,44,47]\end{array}$ & $\begin{array}{l}\text { - Experimental tests on wall-flow DPFs } \\
\text { coated with SCR catalysts has shown } \\
\text { similar NOx reduction performance to } \\
\text { conventional flow-through SCR }\end{array}$ & $\begin{array}{l}\text { - Smaller size and cost of after-treatment system } \\
\text { (one less device) }\end{array}$ & $\begin{array}{l}\text { - Potentially lower SCR } \\
\text { performance due to } \\
\text { coking of SCR catalysts } \\
\text { from soot. }\end{array}$ \\
\hline $\begin{array}{l}\text { Electrically regenerated metal } \\
\text { DPF }[45,49]\end{array}$ & $\begin{array}{l}\text { - Prototypes developed and assessed with } \\
\text { engine bench tests }\end{array}$ & $\begin{array}{l}\text { - Very low fuel penalty with respect to filter } \\
\text { regeneration } \\
\text { - Low-weight structure } \\
\text { - Suitable for Diesel hybrid and range extender } \\
\text { vehicles }\end{array}$ & $\begin{array}{l}\text { - Low filtration efficiency } \\
\text { - Possibly high cost }\end{array}$ \\
\hline $\begin{array}{l}\text { Solid ammonia storage } \\
\text { methods, alternative to urea, } \\
\text { e.g., carbamate [42] and } \\
\text { metal ammines [39] }\end{array}$ & $\begin{array}{l}\text { - Approximately } 70 \% \text { lower system volume } \\
\text { - Equal SCR performance compared to urea } \\
\text { - Simpler delivery system compared to urea } \\
\text { - Freezing not a problem } \\
\text { - Currently undergoing precompetitive } \\
\quad \text { service trials }\end{array}$ & $\begin{array}{l}\text { - Lower recharging frequency during service } \\
\text { - Easier transportation, storage and handling } \\
\text { compared to urea } \\
\text { - Production supported by already existing } \\
\text { infrastructures }\end{array}$ & \\
\hline $\begin{array}{l}\text { Zonal coating of SCR substrate } \\
\text { with high temperature (Fe- } \\
\text { zeolite) and low temperature } \\
\text { (Cu-zeolite) catalysts for } \\
\text { wider operating temperature } \\
\text { range [43] }\end{array}$ & $\begin{array}{l}\text { - Experimental tests have demonstrated an } \\
\text { increase in SCR operating temperature } \\
\text { range }\end{array}$ & - Increased SCR temperature range & \\
\hline LNT + SCR technology [47] & - Prototypes have been developed & $\begin{array}{l}\text { - Ammonia is generated by the LNT } \\
\text { - Less LNT PGM content is needed compared to } \\
\text { LNT-only solutions }\end{array}$ & $\begin{array}{l}\text { - LNT durability } \\
\text { - Precise control of } \\
\text { ammonia production }\end{array}$ \\
\hline $\begin{array}{l}\text { Exhaust on-board monitoring } \\
\text { and diagnostics [40] }\end{array}$ & $\begin{array}{l}\text { - Prototype sensors and systems have been } \\
\text { developed (still not massively produced) }\end{array}$ & $\begin{array}{l}\text { - Enabling engine close-loop control } \\
\text { - Enabling fuel economy and enforcing system } \\
\text { durability } \\
\text { - Increase system safety }\end{array}$ & $\begin{array}{l}\text { - High cost } \\
\text { - Reliability } \\
\text { - Durability }\end{array}$ \\
\hline $\begin{array}{l}\text { Tailored emission control } \\
\text { systems for Diesel mixtures } \\
\text { with biofuels and/or fuel- } \\
\text { flexible engines [35] }\end{array}$ & - In R\&D phase & - Increased performance and fuel economy & \\
\hline $\begin{array}{l}\text { Development of emission } \\
\text { control systems with low } \\
\text { precious metal loadings [41] }\end{array}$ & $\begin{array}{l}\text { - Feasibility has been proven with } \\
\text { experimental tests }\end{array}$ & - Lower system cost & - Durability \\
\hline
\end{tabular}

compression ignition; HD, heavy duty; HPEGR, highpressure loop EGR; JRC, European Commission Joint Research Center; LD, light duty; LNT, lean $\mathrm{NO}_{x}$ trap; LTC, low-temperature combustion; NOx, nitric oxides; NRMM, non-road mobile machinery; NVH, noise vibration harshness; PCCI, premixed charge compression ignition; PM, particulate matter; SRA, strategic research agendas; SCR, selective catalytic reduction; SOC, soot oxidation catalyst; TC, turbocharger; VVA, variable valve actuation; WG, waste gate; WHR, waste heat recovery 
Acknowledgments The authors want to thank the European Commission for funding this work through the Clean European RailDiesel project Seventh Framework Programme 7.2.1.1-Sustainable Surface Transport. Grant agreement no.: 234338.

\section{References}

1. Bower, E., Schönau, N., Skipton-Carter, A., Buchanan, J.: GB rail powertrain efficiency improvements. Report. http://www.ricardo. com/Documents/PRs\%20pdf/PRs\%202012/Q57475 DfT_GB Rail_Diesel_Powertrain_Efficiency_Improvements_Word_ FINĀL_14Mar12.pdf (2012)

2. JRC Report: 2007 Technical Review of the NRMM Directive 1997/68/EC as amended by Directives 2002/88/EC and 2004/26/ EC. http://ec.europa.eu/enterprise/sectors/mechanical/files/nrmm/ final_report_nrmm_review_part_i_en.pdf (2008)

3. Beatrice, C., Rispoli, N., Di Blasio, G., Patrianakos, G., Kostoglou, M., Konstandopoulos, A.G., Imren, A., Denbratt, I., Palacin, R.: Emission reduction technologies for the future low-emission rail diesel engines: EGR vs SCR. SAE technical paper 2013-24-0087. doi:10.4271/2013-24-0087

4. TNO report: Euro VI technologies and costs for heavy duty vehicles, 06.OR.PT.023.2/NG. http://ec.europa.eu/environment/ archives/air/pdf/euro_6.pdf (2006)

5. FURORE network report: R\&D Technology Roadmap. http:// www.furore-network.com/documents/furore_rod_map_final.pdf (2007)

6. NESCCAF/ICCT/SwRI/TIAX report: reducing heavy-duty long haul combination truck fuel consumption and $\mathrm{CO} 2$ emissions. http://www.nescaum.org/documents/heavy-duty-truck-ghg report_final-200910.pdf (2009)

7. National Academy of Science (NAS) report: technologies and approaches to reducing the fuel consumption of medium- and heavyduty vehicles, ISBN 978-0-309-14982-2. http://www.nap.edu/ catalog.php?record_id=12845 (2010)

8. NHTSA report: factors and considerations for establishing a fuel efficiency regulatory program for commercial medium- and heavyduty vehicles. U.S. Department of Transportation. http://www. nhtsa.gov/staticfiles/rulemaking/pdf/cafe/NHTSA_Study_Trucks. pdf (2010)

9. AEA report: reduction and testing of greenhouse gas (GHG) emissions from heavy duty vehicles - Lot 1: Strategy, AEA/ED46904/ Final Report - Issue Number 4. http://ec.europa.eu/clima/policies/ transport/vehicles/docs/ec_hdv_ghg_strategy_en.pdf (2011)

10. TIAX report: European Union greenhouse gas reduction potential for heavy-duty vehicles, TIAX Reference No. D5625. http://www. theicct.org/sites/default/files/publications/ICCT\%20GHG\% 20Reduction\%20Potential final.pdf (2011)

11. TRL/Ricardo report: GB rail powertrain efficiency improvements, RD.12/34001.1. http://www.ricardo.com/Documents/PRs\%20pdf/ PRs\%202012/Q57475 DfT GB Rail Diesel Powertrain Efficiency_Improvements_Word_FINAL__-_Mar12.pdf (2012)

12. Nicol, A.: Heavy-duty diesel engine trends to meet future emissions standards (Euro VI)", AECC Technical Seminar on Heavy-Duty Vehicle Emissions (Euro VI), Brussels. http://www.aecc.be/ content/HD\%20Seminar/7__UK\%20Ricardo_Nicol.pdf (2007)

13. Ruhkamp, L., Kind, M., Laumen, H.J., Maassen, F., Mashida, M., Takeuchi, K., Shinohara, Y. Herrmann, O.E., Kudo, T., Nakagawa, M., Rajamani, V.: Further options for diesel engine improvements by increased injection pressure up to 3000 Bar, 20th Aachen Colloquium Automobile and Engine Technology (2011)

14. de Ojeda, W.: Development and demonstration of a fuel-efficient HD engine, DOE DEER CONFERENCE 2011. http://www1.eere. energy.gov/vehiclesandfuels/pdfs/deer_2011/monday/ presentations/deer11 deojeda.pdf (2011)

15. Schöppe, D., Stahl, C., Dian, V., Krüger, G., Voigt, P., Weigand, A.: The new diesel servo-driven piezo common rail system - the efficient solution for Euro 7 and beyond, 20th Aachen Colloquium Automobile and Engine Technology (2011)

16. Macian, V., Payri, R., Ruiz, S., Bardi, M., Plazas, H.A.: Experimental study of the relationship between injection rate shape and Diesel ignition using a novel piezo-actuated direct-acting injector. Appl. Energy 118, 100-113 (2014). doi:10.1016/j.apenergy. 2013.12.025. ISSN 0306-2619

17. Zamboni, G., Capobianco, M.: Experimental study on the effects of HP and LP EGR in an automotive turbocharged diesel engine. Appl. Energy 94, 117-128 (2012). doi:10.1016/j.apenergy.2012. 01.046. ISSN 0306-2619

18. Xinqun, G., Dou, D., Winsor, R.: Non-road diesel engine emissions and technology options for meeting them, ASABE Distinguished Lecture \#34, pp. 1-24. Agricultural Equipment Technology Conference, 10-13 January 2010, Orlando, Florida, ASABE Publication Number 913C0110. http://elibrary.asabe.org/data/pdf/ 6/nrde2010/2010\%20Lecture\%20Series\%2034a.pdf (2010)

19. van Aken, M., Willems, F., Dirk-Jan, de J.: Appliance of high EGR rates with a short and long route EGR system on a heavy duty diesel engine, SAE paper 2007-01-0906 (2007)

20. Heiermann J., Teetz C., Schneemann A., Bergmann D., Beidl C., Schmitt M.: Optimization of exhaust gas recirculation: reduction of emissions and fuel consumption, 20th Aachen Colloquium Automobile and Engine Technology (2011)

21. Weerasinghe, W. M. S. R., Stobart, R. K., Hounsham, S. M.: Thermal efficiency improvement in high output diesel engines a comparison of a Rankine cycle with turbo-compounding. Appl. Therm. Eng. 30, 2253-2256 (2010). doi:10.1016/j.applthermaleng.2010.04.028. ISSN 1359-4311

22. MAN Press release: The MAN range of engines for mobile machines. http://www.man-engines.com/datapool/mediapool/700/ PR_MAN-Engines_MoMasch_EN.pdf (2010)

23. Uchida, H.: Trends in turbocharging technologies, teview of Toyota CRDL, http://www.tytlabs.co.jp/english/review/rev413epdf/e413 001 uchida.pdf (2007)

24. Eckerle, W.: Overview of high-efficiency engine technologies, DOE DEER CONFERENCE 2011. http://www1.eere.energy.gov/ vehiclesandfuels/pdfs/deer_2011/monday/presentations/deer11_ eckerle.pdf (2011)

25. TNO report MON-RPT-033-DTS-2009-03840: On-road NOx emissions of Euro-V trucks. http://www.leefmilieu.nl/sites/www3. leefmilieu.nl/files/imported/pdf_s/2009-12-02_TNO\%20Rapport On-road\%20NOx\%20emissions $\% 20$ of\%20Euro-V\%20trucks.pdf (2010)

26. Guido, C., Beatrice, C., Napolitano, P.: Application of bioethanol/ $\mathrm{RME} /$ diesel blend in a Euro5 automotive diesel engine: Potentiality of closed loop combustion control technology. Appl. Energy 102, 13-23 (2013). doi:10.1016/j.apenergy.2012.08.051. ISSN 03062619

27. Willems, F., Doosje, E., Engels, F., Seykens, X.: Cylinder pressurebased control in heavy-duty EGR diesel engines using a virtual heat release and emission sensor, SAE paper 2010-01-0564 (2010)

28. Zhang A.: High-efficiency clean combustion for heavy-duty engine, DOE DEER CONFERENCE 2009. http://www1.eere. energy.gov/vehiclesandfuels/pdfs/deer_2009/session6/deer09 zhang.pdf (2009)

29. Rinaldini, C.A., Mattarelli, E., Golovitchev, V.I.: Potential of the Miller cycle on a HSDI diesel automotive engine. Appl. Energy 112, 102-119 (2013). doi:10.1016/j.apenergy.2013.05.056. ISSN 0306-2619

30. Macián, V., Serrano, J.R., Dolz, V., Sánchez, J.: Methodology to design a bottoming Rankine cycle, as a waste energy 
recovering system in vehicles. Study in a HDD engine. Appl. Energy 104, 758-771 (2013). doi:10.1016/j.apenergy.2012.11. 075. ISSN 0306-2619

31. Wang, T., Zhang, Y., Peng, Z., Shu, G.: A review of researches on thermal exhaust heat recovery with Rankine cycle. Renew. Sustain. Energy Rev. 15(6), 2862-2871 (2011). doi:10.1016/j.rser.2011.03. 015. ISSN 1364-0321

32. Singh et al.: Exhaust heat driven Rankine cycle for a heavy duty diesel engine, DOE DEER CONFERENCE 2011. http://www1. eere.energy.gov/vehiclesandfuels/pdfs/deer_2011/wednesday/ presentations/deer11 singh.pdf (2011)

33. Kruiswyk, R.W.: An engine system approach to exhaust waste heat recovery, DOE DEER CONFERENCE 2008, http://www1.eere. energy.gov/vehiclesandfuels/pdfs/deer_2008/session5/deer08_ kruiswyk.pdf (2008)

34. Strategic Research Agendas (SRA) of the European Road Transport Research Advisory Council (ERTRAC). http://www.ertrac.org/ uploads/documentsearch/id7/ertrac-researchinnovation-roadmaps 60.pdf (2011)

35. FP6 European project: aerosol technologies and hierarchical assembly/manufacturing for advanced nano-structured porous materials (ATLANTIS) (FP6-NMP-2004-026678)

36. Asti, M., Merlone Borla, E., Parussa, F.: Biodiesel influence on particulate matter behaviour during active and passive DPF regeneration, SAE Technical Paper 2011-24-0204 (2011). doi:10.4271/ 2011-24-0204

37. Boger, T., Jamison, J.A., Warkins, J. L., Golomb, N. A. Warren, C. J., Heibel, A. K.: Next generation aluminum-titanate material to meet upcoming EU6 emissions legislation requirements. 19th Aachen Colloquium Automobile and Engine Technology (2010)

38. Cavataio, G., Girard, J.W., Lambert, C.K.: Cu/zeolite SCR on highporosity filters: laboratory and engine performance evaluations, SAE Technical Paper 2009-01-0897 (2009)

39. Furuta, Y., Mizutani, Y., Miyairi, Y., Yuki, K., et al.: Study on nextgeneration diesel particulate filter, SAE Technical Paper 2009-010292 (2009)

40. Johannesenn, T.: Compact ammonia storage systems for automotive SCR $\mathrm{NO}_{x}$ control, Presentation at VDI Conference for NOx Control, Nuerenberg, Germany (2009)
41. Konstandopoulos, A., Papaioannou, E., Zarvalis, D., Skopa, S. et al.: Catalytic filter systems with direct and indirect soot oxidation activity, SAE Technical Paper 2005-01-0670 (2005). doi:10.4271/ 2005-01-0670

42. Nakamura, M., Wakamatsu, H., Suga, K., Hiramoto, T. et al.: Ultrafine precious metal catalyst for high conversion efficiency with low-precious metal loading, SAE Technical Paper 2009-011069 (2009). doi:10.4271/2009-01-1069

43. Tatur, M.: Solid SCR demonstration truck application, Presentation at US Department of Energy Directions in Engine Efficiency and Emissions Research (DEER) Conference, Dearborn, Michigan (2009)

44. Theis, J.R.: SCR Catalyst systems optimized for lightoff and steady-state performance, SAE Technical Paper 2009-010901 (2009)

45. Walker, A.P.: Optimising future catalyst systems. Presentation at SAE 2010 Heavy Duty Diesel Emissions Control Symposium (2010)

46. Zarvalis, D., Zygogianni, A., Lorentzou, S., et al.: Performance assessment of a multi-functional reactor under conventional and advanced combustion diesel engine exhaust conditions, SAE Technical Paper 2011-01-0606 (2011)

47. Lee, S.-J., Jeong, S.-J., Kim, W.-S.: Numerical design of the diesel particulate filter for optimum thermal performances during regeneration. Appl. Energy 86(7-8), 1124-1135 (2009). doi:10.1016/j. apenergy.2008.07.002. ISSN 0306-2619

48. Guan, B., Zhan, R., He, L., Huang, Z.: Review of state of the art technologies of selective catalytic reduction of NOx from diesel engine exhaust. Appl. Therm. Eng. 66(1-2), 395-414 (2014). doi:10.1016/j.applthermaleng.2014.02.021. ISSN $1359-4311$

49. Aerosol technologies and hierarchical assembly/manufacturing for advanced nano-structured porous materials (ATLANTIS) (FP6NMP-2004-026678)

50. Dilip, K.V., Vasa, N.J., Carsten, K., Ravindra, K.U.: Incineration of diesel particulate matter using induction heating technique. Appl. Energy 88(3), 938-946 (2011). doi:10.1016/j.apenergy.2010.08. 012. ISSN 0306-2619 